\title{
Use of Phytomeliorant Plants for Waste Water Purification
}

\author{
Akmaral U. Issayeva', Arystanbek A. Yeshibayev', Assel Ye. Tleukeyeva², \\ Yerzhan B. Issayev² \\ 1 Shymkent University, Shymkent, Karatau district 225, built 426, Kazakhstan \\ 2 M.Auezov South Kazakhstan University, Tauke khan avenue, 5, Shymkent, 160000, Kazakhstan 5 \\ * Corresponding author's email: aseltleukeyeva@mail.ru
}

\begin{abstract}
The use of phytomeliorant plants is one of the promising trends in environmental biotechnology to purify waste water. The study was carried out to understand the phytomeliorative qualities of plants of the indigenous flora of the Turkestan Region under controlled conditions and to develop a method for treating wastewater. It was established that the use of a three-stage treatment of municipal wastewater using phytomeliorant plants: Ceratophyllum demersum L., Potamogeton trichoides Cha. Et Schlecht., Potamogeton pectinatus L., Potamogeton natans L.; Cardamine densiflora N. Gontsch., Sium sizaroideum DC.; Veronica beccabunga L, Veronica anagallis - aquatica L. and Azolla caroliniana Willd for 30 days of the controlled experiment reduces the content of organic and mineral ingredients to the MPC values. A method for phyto-meliorative wastewater treatment of one of the sanatoriums in the south of Kazakhstan was developed and carried out in multi-stage bioponds, where water was purified from mineral and organic compounds by $94.9 \pm 8.3-98.9 \pm 7.8 \%$ in 12 days. In this study, first of all, nitrogenous compounds were utilized, then there was an active absorption of mineral ions and residual organic matter by plants. In conclusion, significant purification of wastewater was achieved by using indigenous phytomeliorant plants in much shorter time period.
\end{abstract}

Keywords: phytomeliorant plants, wastewater, purification, toxic ingredients, phytoremediation.

\section{INTRODUCTION}

One of the promising directions of using the vital activity of higher plants is their application in the purification of anthropogenically polluted waters. Hydromacrophytes, by their biological nature, are powerful filters that are utilized to the purification of aqueous solutions [Kłosowski, 2001]. Macrophytes or higher aquatic vegetation affect the chemical and physical properties of water. They serve as a powerful biological filter in the process of natural self-purification of water bodies [Moore, 1994]. Intensification of the self-purification processes of waters from various pollutants using higher aquatic vegetation (HAP) in symbiosis with other parts of the ecosystem in most cases turns out to be an economical and effective method. In the course of evolution, vegetation has developed a number of defense mechanisms, and its presence contributes to the decomposition of many chemical compounds. By releasing organogenic oxygen and aerating water, HAP promotes the oxidation of organic substances by bacteria, while simultaneously using the resulting decay products for their vital activity. In some cases, the degree of removal of organic impurities using macrophytes is higher than when using industrial methods of water purification in aerotanks. Sometimes it is possible to reduce the total biogenic load on the reservoir up to $47 \%$ [Aalami, 2018]. For example, in one of the lagoons of Lake Biwa (Japan), the amount of total nitrogen was reduced by $38.5 \%$, total phosphorus by $93.0 \%$ of their annual input with domestic wastewater [Agula, 2018]. Experiments have been carried out for the neutralization of oil and oil products, pesticides, mineral fertilizers and herbicides, triphenylmethane dyes, aromatic and aliphatic amines, phenolic and mercapto compounds, heavy metal compounds, thiocyanide and cyanide-containing wastewater using HAP. 
If terminological inconsistencies when naming various structures using the properties of HAP are not taken into account, their fundamental difference is their functional purpose, e.g. the structure (or a natural, overgrown HAP, site) acts as a wastewater treatment facility or this structure was created to improve the quality of natural waters. The first group of structures includes botanical sites, bioponds with HAP plantings, artificial wetlands and bioengineering structures for regulating the water quality. The second group includes phyto-filtration devices and various types of bioplato [Balzan, 2018].

Botanical sites are shallow water areas of arbitrary configuration with thickets of HAP of natural origin with an area from several units to tens of hectares, created in the existing depressions of the terrain or in specially bounded areas. In most cases, HAPs are represented by common reed, narrow-leaved and broad-leaved cattail, and lacustrine reeds. Botanical sites are mainly used for the purification and post-treatment of wastewater from the mining and chemical industries. The degree of water purification from nitrogen compounds at such sites ranges from $2.5-97 \%$, from heavy metals - 14-90\%, while that from oil and oil products can reach almost 100\% [Chernicharo, 2015].

On experimental sites, reeds remove $94 \%$ of nitrogen, reed and cattail, i.e. -78 and $28 \%$, respectively [Oliveira, 2011]. On a site without vegetation, the amount of nitrogen decreases by $11 \%$. The high efficiency of nitrogen removal in the areas with reeds is sometimes associated with their ability to transfer oxygen to the root zone. The cattail lacks this ability. The efficiency of nitrogen removal is significantly increased under the conditions of an abundant supply of carbon, which is a part of dissolved organic substances, and at low speeds of water movement. The upper limit of nitrogen absorption by reeds, reeds and cattail is about $0.1 \mathrm{~g} / \mathrm{m}^{2}$ per day [Bortolini, 2018]. In addition, the permanganate oxidizability of water and biochemical oxygen consumption are significantly reduced at the botanical sites that pass wastewater from livestock complexes, the saturation of water with oxygen increases, and organoleptic and sanitary-bacteriological indicators are improved. According to various authors, the normal load during the active growing season of macrophytes per $\mathrm{m}^{2}$ varies within $0.2-2.0 \mathrm{~m}^{3} / \mathrm{m}^{2}$ per day with the development of 100-200 reed, cattail or reed stems [Von Sperling, 2009].
The fundamental difference between biological ponds with HAP plantings is the presence of an algobacterial complex, in particular, the Chlorella vulgaris culture, which is widespread in the reservoirs of southern Kazakhstan. Chlorella efficiently purifies polluted water, in subsequent biomass which can be used as fertilizer in agriculture [Tleukeyeva, 2021]. The introduction of HAP then allows the use of an additional cleaning mechanism inherent in macrophyte communities (mineralizing activity of the HAP periphyton, absorption and accumulation of HAP properly, as well as phyto- and bacterioplankton inhabiting their thickets, etc.). In such structures, the nitrogen content is reduced by $10-80 \%$, organic matter - by $90 \%$, oil and oil products - by $60 \%$, suspended solids - by $98 \%$. An additional factor of wastewater treatment in artificially swampy areas in comparison with botanical sites is the filtration of water through the root layer of soils. Such structures purify wastewater from ammonium nitrogen by $30-60 \%$, nitrites by $10-20 \%$, and reduce BOD 5 by $50-70 \%$ [Piperd, 2013].

In order to improve and intensify the natural treatment properties of HAP and associated organisms, as well as to combine mechanical and biological wastewater treatment, various designs of artificial bioengineered water protection structures are being created, where the water flow is filtered both in the horizontal and vertical planes. HAPs occupy $100 \%$ of the water area of the structures and are represented by common reed, narrow-leaved cattail, and lake reeds. Other combinations of the main types of HAP are also known. Thus, the technology for reducing the content of synthetic surfactants in water is based on the combined use of Canadian Elodea and air-water (narrow-leaved cattail) vegetation. For such structures, a decrease in the concentration of ammonium nitrogen by $80-92 \%$, nitrogen nitrite by $94-99 \%$, nitrogen nitrate by $60-96 \%$, phosphate by $96-99 \%$, organic matter by $40-80 \%$, suspended solids by $88-99 \%$ was obtained [Adams, 1971]. The water quality indicators such as color and $\mathrm{pH}$ improved. Different types of bioplato are fundamentally different from the water protection structures considered above, in which HAP communities of natural or artificial origin are used as biofilters to improve the quality of natural waters. The main purpose of bioplato is to neutralize alloand autochthonous sources of pollution of water bodies of artificial origin. Currently, several types 
of bioplato are known, e.g. coastal, channel, estuary, floodplain and infiltration.

Biological ponds and phytotechnologies are used in wastewater treatment. In Europe, these methods and developments have been widely studied [Khan, 2013]. Thus, the integrated phyto-purification system (PPS) is quite widespread in Italy and other countries. The developed system of biocenosis of higher plants in ISF makes it possible, with the efficiency up to the EU standards, to bring wastewater to the standard indicators of discharge and reuse [Mitsch, 2004]. The biological methods of purification make it possible to oxidize organic compounds of the aliphatic series, amyl ethyl and methyl alcohols, acetone, glycols, glycerin, aniline and many other substances. With long-term adaptation to these pollutants of microbiological cenoses in treatment facilities, it is possible to achieve oxidation of even such stable compounds as toluene, xylene, hydrocarbons, oil, etc. [McGrath, 2002].

A high purifying effect of HAP is achieved where water flows through a community of semi-submerged, floating and submerged plants. The mucus (periphyton) on the surface of plants, as well as a decrease in the rate of fluid flow in the overgrown zones, promotes the deposition of suspended solids of organic and mineral origin in water [Vymazal, 2009]. In the presence of higher aquatic plants, oil decomposes 3-5 times faster [Mustapha, 2018]. One cane plant weighing $100 \mathrm{~g}$ can extract up to $4 \mathrm{mg}$ of phenol from water [Simi, 2000]. In addition to phenol, its derivatives (pyrocatechol, resorcinol, xylene, etc.) are also absorbed. In the processes of photosynthetic aeration, macrophytes play no lesser a role than phytoplankton. They are able to accumulate various elements in their body. The data above allow concluding that the most rational methods of wastewater treatment are biological, using phytotechnologies, that is, wastewater treatment methods based on the use of natural self-cleaning processes of water bodies, using higher aquatic vegetation, aquatic microflora and microorganisms. The aim of the study was to study the phytomeliorative qualities of plants of the indigenous flora of the Turkestan Region under experimental conditions and to develop a method for treating wastewater for one of the enterprises in the south of Kazakhstan.

\section{MATERIALS AND METHODS}

The wastewater samples were collected from the "Burguluk" sanatorium, located in the Turkestan Region. The municipal wastewater of this region contains a number of toxic ingredients, including a synthetic surfactant having the composition shown in Table 1.

Sampling and hydrochemical analyses of water were carried out in accordance with the conditions of GOSTs 18826-73, 4388-72, 18293-72, $18309-72$, 4245-72, 3351-74, 4979-49, 4151-72 and 18293-73, as well as according to the generally accepted methodology of Katanskaya [Katanskaya, 1981]. The content of heavy metal ions in the aqueous medium was determined on the STA - 1 complex, by the stripping voltammetry method and the atomic adsorption method on an AAS 1 spectrophotometer. The ions of chlorides, sulfates, nitrates and nitrites were determined by using the photocolorimetric method on a CFK photometer-3-01-ZOMZ and the ionometric method on the I-500 ionomer. In order to determine the species composition of plants, the

Table 1. Initial chemical composition of municipal wastewater in Turkestan Region

\begin{tabular}{|c|c|c|c|c|}
\hline No. & Ingredients & Unit rev. & Content & MPC \\
\hline 1 & Ammonium & $\mathrm{mg} / \mathrm{dm}^{3}$ & 6.72 & 0.5 \\
\hline 2 & Nitrites & $\mathrm{mg} / \mathrm{dm}^{3}$ & 1.61 & 0.02 (byN) \\
\hline 3 & Nitrates & $\mathrm{mg} / \mathrm{dm}^{3}$ & 11.10 & 9.10 (byN) \\
\hline 4 & Phosphates & $\mathrm{mg} / \mathrm{dm}^{3}$ & 6.70 & 3.5 \\
\hline 5 & Chlorides & $\mathrm{mg} / \mathrm{dm}^{3}$ & 55.4 & 300 \\
\hline 6 & Petroleum products & $\mathrm{mg} / \mathrm{dm}^{3}$ & 0.23 & 0.30 \\
\hline 7 & Copper $\left(\mathrm{Cu}^{+2}\right)$ & $\mathrm{mg} / \mathrm{dm}^{3}$ & 4.50 & 1.00 \\
\hline 8 & Zinc $\left(\mathrm{Zn}^{+2}\right)$ & $\mathrm{mg} / \mathrm{dm}^{3}$ & 4.50 & 1.00 \\
\hline 9 & Lead $\left(\mathrm{Pb}^{+2}\right)$ & $\mathrm{mg} / \mathrm{dm}^{3}$ & 1.51 & 0.03 \\
\hline 10 & Cadmium $\left(\mathrm{Cd}^{+2}\right)$ & $\mathrm{mg} / \mathrm{dm}^{3}$ & 0.005 & 0.001 \\
\hline 11 & $\mathrm{BOD}_{5}$ & $\mathrm{mg} \mathrm{O}_{2} / \mathrm{dm}^{3}$ & 18.80 & 3.00 \\
\hline
\end{tabular}


corresponding literature was used [Lee, 2018]. Sampling of plants was carried out according to the method of route survey, followed by office processing of the collected herbarium material under laboratory conditions.

The laboratory studies to determine the effect of various pollutants on the morphometric parameters of aquatic plants were carried out in glass vessels with a capacity of 3 and 10 liters, at an ambient temperature of $180^{\circ} \mathrm{C}$, illumination of 4000 lux and artificial aeration of water. The duration of the experiment was 10-20 days, during which phenological observations of the experimental plants were carried out. The rate of such processes as indicators of stem growth, the formation of new leaves, wilting of stems and leaves, blackening and decay of individual parts of plants were recorded. Changes in the studied characteristics were ascertained in comparison with the indicators of the control variant. Statistical analysis of the obtained results was carried out by calculating the arithmetic mean and the standard deviation at $0.95>\mathrm{P}>0.80$. All determinations were carried out in 3 and 5 replications. The data were processed using an IBM Pentium personal computer based on the MS Excel application software packages.

\section{RESULTS AND DISCUSSION}

\section{Study of the role of phytomeliorant plants in wastewater treatment}

Pollution of water resources in the Turkestan region (TR), located in the south of Kazakhstan, represents diverse components, both natural mineral and anthropogenic. Most of the rivers are low-water and originate from the glaciers of the Tien Shan. Initially clean rivers, flowing through settlements, actually accumulate organic, chemical and mineral pollution. Economic growth leads to an increase in suspended solids, organic compounds, phosphates, nitrates and other substances in water [Li, 2018]. Many types of anthropogenic activities contribute to the formation of secondary waste products, the formation of new types of xenobiotics [MacIvor, 2018]. The industrialization and intensification of the development of the agro-industrial complex in many countries led to the saturation of water resources with biogenic elements, which as a result caused the eutrophication of reservoirs, which later led to either waterlogging or salinization of the reservoir. Further development prospects show a decrease or change in the biodiversity of the reservoir due to changes in the hydrochemical and hydrological characteristics [Martinuzzi, 2018].

The main pollutants of water bodies are heavy metal ions, biogenic elements: nitrogen and phosphorus, organic compounds. At the same time, water resources are polluted by one or another ingredient, depending on the settlements that the river flows past. For example, the main sources of nitrogen and phosphorus entering the rivers from the environment are atmospheric nitrogen deposition as a result of natural fuel combustion, rock leaching, urban and industrial wastewater discharge, washing nitrogen and phosphorus-containing fertilizers from the fields, which is confirmed for other regions [Mor, 2018]. Heavy metal ions can infiltrate into the water with household garbage, and organic compounds from livestock complexes.

The idea of using phytomeliorant plants of the native flora of the south of Kazakhstan in wastewater treatment arose on the basis of previously obtained results on the correlation between the hydrological, hydrothermal and hydrochemical parameters of the reservoir and the species composition of hydrophytocenosis [Nedelciu, 2018]. These parameters change significantly as the geographical level decreases, in the direction of which all the rivers of the TR flow. In addition, the level of technogenic load on water sources associated with the receipt of surface wastewater from settlements, agricultural landscapes and industrial territories of enterprises is growing in the same direction [Noori, 2018]. The combination of these factors significantly affects the process of formation of aquatic vegetation communities.

Floristic studies of the community of hydromacrophytes were carried out in the period of 2010-2016 on 17 rivers, 8 reservoirs and 2 ponds-accumulators of technogenic wastewater from industrial zones of the TR. As a result of the research, 57 species of aquatic plants were identified, which is $38.5 \%$ of the 148 species found on the territory of the whole of Kazakhstan. Among the established plant species, a new plant species was established for the first time for the flora of Kazakhstan in 2008 - Azolla caroliniana Willd., which is a representative of the department of ferns - polypodiophyta, whose distribution areas are defined in the basins of the Koshkar-Ata and Aksu rivers [Pratiwi, 2018]. In addition to higher 
vascular plants, a certain part of the hydrophytocenosis of these reservoirs is made up of some representatives of the department of algae and mosses, such as green moss Fontinalisantipyretica Linnt., Chara vulgaris L. and Riccia natans $L$., which form independent plant formations and associations in separate biotopes.

The conducted studies on the algorithm are similar to the studies of Purvis et al. [Purvis, 2018], which revealed a relationship between the chemical composition of waters and changes in the structure of the macroinvertebrate population. Macroinvertebrates were used as a bio-assessment indicator to determine the environmental quality of given water body, just as in the case of performed studies, where the structure of the population of hydromacrophytes was used as bioindicators. As a result of the conducted studies, the following populations were identified:

1. indicators of a clear water environment with a reduced temperature - Azolla caroliniana Willd., Veronica beccabunga L., Veronica anagallis-aquatica L., Cardamine densiflora $N$. Gontsch. And Riccia natans L.;

2 . indicators of a highly polluted water with moderate temperature and mineral ions-Sium sizaroideum DC., Potamogeton trichoides Cha. et Schlecht., Poligonum amphibium L., Veronica beccabunga L., Chara vulgaris $L$. and Mentha aquatica $L$;

3. indicators of an aquatic environment heavily polluted with mineral and organic substances with a moderate temperature-Ceratophyllum demersum L., Potamogetum pectinatus L., Potamogeton natans L., Fontinalis antipyretica Linnt and Phragmites australis Trin.;

4. indicators of the aquatic environment, heavily polluted with mineral and organic substances Ph. australis Trin, S. sagittifolia L., T. latifolia L., L. minor L., S. lacustris L., L. trisulca $L$. and $C$. demersum $L$. Dominant and subdominant species were identified for each population.

It was the visual picture of the formed hydrophytocenosis on a reservoir with certain hydrological characteristics and an already established level of water pollution that prompted the idea of using plants of certain ecotopes for wastewater treatment. On the other hand, in most studies, plants structurally different in their habitat are preferred for the selection of phytomeliorant plants in the composition for the phytomeliorative treatment of polluted waters: floating on the surface-growing in the water column and coastal [Qiu, 2018]. In addition, it was shown that it is possible to use a consortium of higher aquatic plants with microorganisms to reduce the content of biogenic components in the aquatic environment [Radonic, 2018]. For laboratory studies, the dominant species of hydromacrophytes were selected, which were conditionally divided by the habitat conditions into three groups of ecological biotopes:

1. Species of pure and moderately polluted biotope with mineral substances - Azolla caroliniana Willd., Veronica anagallis-aquatica L. and $V$. beccabunga L.;

2. Types of biotope moderately polluted with mineral and organic substances - Sium sizaroideum, Cardamine densiflora N. Gontsch.;

3. Species of biotope heavily polluted with mineral and organic substances - Potamogeton pectinatus L., P. trichoides Cha. Et Schlecht., P. natans L. and Ceratophyllum demersum L.

The results of the experiments showed that the dominant plant species of the first and second biotopes do not survive in the environment of municipal wastewater with the initial concentration of pollutants. On the third day of the experiments, all studied plant species showed signs of oppression and died on the fifth day; this confirms the natural reaction of unadapted plant species to high concentrations of toxic ingredients [Saeed, 2018]. The chemical analysis of water showed that the decrease in the concentration of pollutants does not exceed $2.8 \pm 0.15$ and $15.7 \pm 0.84 \%$, respectively.

Therefore, it was decided to use the recultivation properties of plants of different biotopes in a sequential chain of step-by-step wastewater treatment, depending on the plant species adapted to certain concentrations of toxic ingredients. It was supposed to use alternately plants of the third biotope - for the first stage of purification of the initial wastewater, plants of the second biotope for the second stage of purification and, finally, plants of the first biotope for additional water treatment at the final stage. The use of variations of plant species or their compositions is practiced for the purification of various types of polluted waters [Salgado, 2018].

For this purpose, in the first 10 days, in the experimental variant, the plants of the third biotope were grown, as the most adapted to the conditions of water polluted with organic substances. After 10 days, the plants were changed 
to the species of the second dominant biotope of the moderately polluted aquatic environment. At the final stage of the experiment, the plants of the first biotope were grown in an aqueous medium previously purified in the previous stages for 10 days. As results of the experiments, the dominant species of the third biotope continued their vegetation until the end of the experiment. The chemical analyses of the samples after 10 days of exposure showed that the content of the main pollutants decreased by $45.9 \pm 2.6-75.9 \pm 4.8 \%$. At the same time, it was revealed that plants absorb large quantities of nitrate, ammonium forms of nitrogen and chlorides, which is comparable to the known data. The results of daily chemical analyses of water in the experimental version revealed that the active process of absorption of pollutants by plants occurs on the first day of the experiment. It was found that $45.5 \pm 2.8$ $57.9 \pm 4.2 \%$ of the absorption of nitrates, ammonia and phosphates occurred in the first three days of the experiment.

In the following days, this process was more uniform. In general, by the end of the experiment, the concentrations of nitrates, nitrites, ammonia, phosphates and chlorides in the aquatic environment decreased $2.4 \pm 0.13-3.1 \pm 0.25$ times, which significantly affected the rate of biochemical processes. The $\mathrm{BOD}_{5}$ indicator of the aquatic environment for 10 days of the experiment decreased by $56.7 \pm 3.5 \%$. During the same period, the decrease in the concentration of lead, cadmium and oil products in water was $25.2 \pm 1.6,19.4 \pm 0.54$, and $32.3 \pm 1.9 \%$, respectively. A decrease in the concentration of nitrogenous substances and the rate of biochemical processes of organic decomposition changed the trophic reserves of the aquatic environment and brought them closer to optimal conditions for the plant species of the second biotope. Therefore, after the end of the experiment, the plants of the second biotope were placed in the aquatic environment. The results of the experiment showed that the plants of the second biotope over the same period reduce the concentration of the main types of pollutants by another $20.6 \pm 1.0-23.7 \pm 1.7 \%$, and heavy metal ions, respectively, from $23.6 \pm 1.6$ up to $44.6 \pm 3.3 \%$. As it can be seen from Table-2, after the experiment with the plants of the second biotope, the pollution of the aquatic environment for all ingredients slightly exceeds the MPC values and is
Table 2. Chemical composition of municipal wastewater after experiment with the plants of the second biotope

\begin{tabular}{|c|c|c|c|}
\hline S. No. & Ingredients & Unit rev. & Content \\
\hline 1 & Ammonium & $\mathrm{mg} / \mathrm{dm}^{3}$ & 1.23 \\
\hline 2 & Nitrites & $\mathrm{mg} / \mathrm{dm}^{3}$ & 0.04 \\
\hline 3 & Nitrates & $\mathrm{mg} / \mathrm{dm}^{3}$ & 2.10 \\
\hline 4 & Phosphates & $\mathrm{mg} / \mathrm{dm}^{3}$ & 1.20 \\
\hline 5 & Chlorides & $\mathrm{mg} / \mathrm{dm}^{3}$ & 12.2 \\
\hline 6 & Petroleum products & $\mathrm{mg} / \mathrm{dm}^{3}$ & 0.02 \\
\hline 7 & Copper $\left(\mathrm{Cu}{ }^{+2}\right)$ & $\mathrm{mg} / \mathrm{dm}^{3}$ & 1.50 \\
\hline 8 & Zinc $\left(\mathrm{Zn}^{+2}\right)$ & $\mathrm{mg} / \mathrm{dm}^{3}$ & 1.50 \\
\hline 9 & Lead $\left(\mathrm{Pb}^{+2}\right)$ & $\mathrm{mg} / \mathrm{dm}^{3}$ & 0.06 \\
\hline 10 & Cadmium $\left(\mathrm{Cd}{ }^{+2}\right)$ & $\mathrm{mg} / \mathrm{dm}^{3}$ & 0.002 \\
\hline 11 & $\mathrm{BOD}_{5}$ & $\mathrm{mg} \mathrm{O} / \mathrm{dm}^{3}$ & 4.30 \\
\hline
\end{tabular}

close to the habitat of plants of the first biotope in terms of hydrochemical parameters.

The use of dominant species of a pure and moderately contaminated biotope with minerals contributed to a further decrease in the concentration of all ingredients to the MPC values, except for chlorides, the content of which in the water after the third stage of phytoremediation exceeded the MPC indicator by 1.2 times. The analysis of the results of the experiments showed that the use of a three-stage treatment of municipal wastewater by various groups of plants within 30 days of the model experiment made it possible to reduce the pollution of the water environment with organic and mineral substances to the MPC values. At the same time, the picture of utilization of pollutants by phytopurification stages turned out to be as follows:

- Stage-1 of purification - the use of the plant community of $C$. demersum L., P. trichoides Cha. Et Schlecht., P. pectinatus L. and P. natans L. for 10 days cleans the aquatic environment from organic compounds by $70.5 \pm 4.9 \%$ and mineral by $35 \pm 1.6 \%$

- Stage-2 of purification - the use of the plant community of the $C$. densiflora $N$. Gontsch. and $S$. sizaroideum. In 10 days cleans the aquatic environment from organic compounds by $25.5 \pm 1.9 \%$ and mineral by $55 \pm 3.6 \%$

- Stage-3 of purification - the use of the plant community of $V$. beccabunga $\mathrm{L}, V$. anagallis - aquatica L. and A. caroliniana Willd in 10 days clears the aquatic environment from organic compounds by $2.5 \pm 0.13 \%$ and mineral by $6.4 \pm 0.2 \%$. 


\section{Using the developed method of phytomeliorative wastewater treatment of the "Burguluk" sanatorium}

The results obtained served as the basis for the development of a scheme for the use of dominant plant species of the local flora in the treatment of municipal wastewater, which was tested at the treatment facilities of the Burguluk sanatorium in the Tolebi district. At present, the existing sanatorium purification system has the following scheme: sewage flows into a $4 \times 8$ $\mathrm{m}$ receiving pond, where metal grates are installed to separate large mechanical impurities. From the receiving pond, wastewater flows into a $7 \times 25 \mathrm{~m}$ storage pond, where there is a permanent plant community, consisting mainly of coastal vegetation such as Phragmites australis Trin. and Poligonum amphibium L. of the truly hydrophytic forms of vegetation, only Potamogeton natans $\mathrm{L}$. is found. The projective cover of the water surface by vegetation was estimated at no more than $20 \%$, the current speed was $0.12-0.25 \mathrm{~m} / \mathrm{s}$, and the depth was $1.3-2.0 \mathrm{~m}$. Into the third pond, water seeps through a gravelly-sandy sleeve provided between the second and third ponds. However, due to the lithogenetic feature of the soil profile of the area, most of the water from the second pond is filtered into deeper soil layers, as a result of which the third pond does not fill up and does not fulfill its projective function. The fourth pond is empty for the above reason. In the coastal zone and the aquatic environment of the third and fourth ponds, vegetation is completely absent. Since the specified system of bioponds is located at an altitude of $80 \mathrm{~m}$ from the terrain level, seepage flows are directed down to the Burguluk River, which flows at the base of the hill. Filtration streams near the banks of the river come to the surface in the form of a small stream and merge with the river. The chemical analysis of the water of the first and third ponds showed that the content of mineral ions and various forms of nitrogen ranges from $17.3 \pm 1.2$ to $28.8 \pm 2.1 \mathrm{MPC}$, $\mathrm{BOD}_{5}-35.5-46.6 \mathrm{mgO}_{2} / \mathrm{dm}^{3}$. The established facts show the unsatisfactory quality of operation in this wastewater treatment plant.

The production test of the model of phytoreclamation of municipal wastewater was carried out in the second, third and fourth ponds of the above-mentioned treatment plant, the "Burguluk" sanatorium. At the edge of each pond, plastic blocks were fenced off with plots $2 \times 2$ $\mathrm{m}$ in size and $0.7 \mathrm{~m}$ deep. The flow of water entering and leaving the blocks was regulated through an opening with a diameter of $1.0 \mathrm{~cm}$. The water through the outlet entered a hose through which it flowed into the second and through it into the third blocks. This scheme provided for a four-stage phyto-purification system. The first stage of treatment is a receiving pond designed to purify water from large impurities, the second, third and fourth stages are bioponds with a different species composition of the hydromacrophyte community.

The plant biomass in each treatment block was $1.5-2.0 \mathrm{~kg} / \mathrm{m}^{3}$. The speed of the water flow did not exceed $0.01-0.015 \mathrm{~m} / \mathrm{s}$. The test results showed that the decrease in the concentration of all pollutants when leaving the biopond No. 3 is $94.9 \pm 8.3-98.9 \pm 7.8 \%$. The results obtained show that in the process of phyto-purification, first of all, nitrogenous compounds are utilized, which is carried out by dominant plant species adapted to the conditions of an aquatic environment polluted with organic substances. In the subsequent stages of phytoremediation, plants actively absorbed mineral ions and residual organic matter. The calculated amount of plant biomass per $1 \mathrm{~m}^{3}$ of water and the hydrological parameters of the runoff are optimal for the completeness of the process of water purification by recultivating plants (Table 3 ).

In order to achieve high efficiency of the developed method of municipal wastewater phytoremediation, it is necessary to provide the following conditions:

1. the main mass of the plant community of each biopond should be dominant plant species of the biotope corresponding to the hydrochemical characteristics of the aquatic environment of the biopond;

2. the components of the plant community should be represented by species inhabiting different depths and surface of the water [Straupe, 2018];

3. to increase the efficiency of phyto-purification, it is necessary to create the conditions for the development of a community of coastal vegetation such as Scolochloa festucacea Link., Phragmites australis Trin., Typha latifolia L., Poligonum amphibium L.;

4. it is necessary to provide the calculated amount of the phytomass of hydromacrophytes per unit area of the biopond [Sudarsan, 2018];

5. the addition or renewal of the vegetation cover of bioponds should be carried out on the basis 
Table 3. The main parameters of the method of phytoremediation of municipal wastewater in step bioponds

\begin{tabular}{|c|c|c|c|c|c|c|c|c|c|}
\hline \multirow{2}{*}{$\begin{array}{l}\text { S. } \\
\text { No. }\end{array}$} & \multirow{2}{*}{$\begin{array}{l}\text { Names of the } \\
\text { stages of the } \\
\text { treatment system }\end{array}$} & \multirow{2}{*}{$\begin{array}{c}\text { Species } \\
\text { composition of } \\
\text { the community of } \\
\text { hydromacrophytes }\end{array}$} & \multirow{2}{*}{$\begin{array}{c}\text { Sizes of } \\
\text { bioponds } \\
(\mathrm{m})\end{array}$} & \multirow{2}{*}{$\begin{array}{c}\text { Water } \\
\text { depth }(m)\end{array}$} & \multirow{2}{*}{$\begin{array}{l}\text { Water flow } \\
\text { velocity } \\
(\mathrm{m} / \mathrm{s})\end{array}$} & \multicolumn{4}{|c|}{ Reducing the concentration of pollutants, $\%$} \\
\hline & & & & & & Nitrates & Nitrite & Phosphates & $\mathrm{BOD}_{5}$ \\
\hline 1 & 2 & 3 & 4 & 5 & 6 & 7 & 8 & 9 & 10 \\
\hline 1 & $\begin{array}{l}\text { Pond for water } \\
\text { purification from } \\
\text { mechanical } \\
\text { impurities }\end{array}$ & - & $3 \times 4$ & $0.7 \times 1.0$ & $0.5-0.7$ & - & - & - & - \\
\hline 2 & $\begin{array}{l}\text { Plant community } \\
\text { biopond resistant } \\
\text { to high levels of } \\
\text { organic pollutants }\end{array}$ & $\begin{array}{l}\text { Ph. australis Trin., } \\
\text { T. latifolia L., L. } \\
\text { minor L.,P. natans } \\
\text { L., P. pectinatus } \\
\text { L., C. demersum } \\
\text { L, F. antipyretica } \\
\text { Linnt. }\end{array}$ & $10 \times 30$ & $0.7 \times 1.0$ & $0.01-0.01$ & $78.8 \pm 3.4$ & $69.6 \pm 6.3$ & $45.5 \pm 3.3$ & $65.8 \pm 5.5$ \\
\hline 3 & $\begin{array}{c}\text { Biopond of a } \\
\text { community of plant } \\
\text { species resistant } \\
\text { to medium organic } \\
\text { and high levels of } \\
\text { mineral pollutants }\end{array}$ & $\begin{array}{l}\text { P. natans L., C. } \\
\text { demersum L., } \\
\text { C. densiflora } \\
\text { N. Gontsch., S. } \\
\text { sizaroideum DC. }\end{array}$ & $8 \times 20$ & $0.7 \times 1.0$ & $\begin{array}{l}0.01- \\
0.015\end{array}$ & $93.8 \pm 4.9$ & $89.7 \pm 7.4$ & $85.2 \pm 6.3$ & $78.8 \pm 6.5$ \\
\hline 4 & $\begin{array}{c}\text { Biopond of plant } \\
\text { communities that } \\
\text { effectively cleanse } \\
\text { the aquatic } \\
\text { environment from } \\
\text { mineral ions }\end{array}$ & $\begin{array}{l}\text { V. beccabunga L., } \\
\text { C. demersum L., } \\
\text { C. densiflora N. } \\
\text { Gontsch. }\end{array}$ & $8 \times 20$ & $0.7 \times 1.0$ & $\begin{array}{l}0.01- \\
0.015\end{array}$ & $98.9 \pm 7.8$ & $97.8 \pm 6.6$ & $98.9 \pm 8.8$ & $94.9 \pm 8.3$ \\
\hline 5 & $\begin{array}{l}\text { Biopond of the } \\
\text { community of plant } \\
\text { indicators of clean } \\
\text { and moderately } \\
\text { polluted aquatic } \\
\text { environment }\end{array}$ & $\begin{array}{l}\text { V. beccabunga } \\
\text { L., V. anagallis- } \\
\text { aquatica L., A. } \\
\text { caroliniana Willd. }\end{array}$ & $5 \times 10$ & $1.0 \times 1.5$ & $0.1-0.2$ & 99.5 & 98.3 & 99.1 & 95.3 \\
\hline
\end{tabular}

of the hydrochemical parameters of water when leaving the treatment system in bioponds. The developed method of phytoremediation of municipal wastewater, while ensuring the above reasonable parameters of functioning, can be highly effective in the system of purification of wastewater and wastewater of private enterprises with a daily load of up to $250 \mathrm{~m}^{3}$.

\section{CONCLUSIONS}

It was found that the use of a three-stage treatment of municipal wastewater with community of Ceratophyllum demersum L., Potamogeton trichoides Cha. Et Schlecht., Potamogeton pectinatus L. and Potamogeton natans L.; at the 2nd stage of purification - plant communities of Cardamine densiflora N. Gontsch. and Sium sizaroideum DC.; at the 3rd stage of purification - the plant communities of Veronica beccabunga L, Veronica anagallis-aquatica L. and Azolla caroliniana Willd for 30 days of the model experiment allowed reducing the pollution of the aquatic environment with organic and mineral substances to the MPC values.

A method was developed for phyto-reclamation of the wastewaters of the "Burguluk" sanatorium in multistage bioponds, which provides water purification from mineral and organic compounds by $94.9 \pm 8.3-98.9 \pm 7.8 \%$ in 12 days. It was established that in the process of phyto-purification, first of all, nitrogenous compounds are utilized; at the subsequent stages of phyto-cultivation, there is an active absorption of mineral ions and residual organic matter by plants.

\section{Acknowledgments}

The study was carried out within the framework of the grant MES RK APO09563499 "Optimization of the functioning of decentralized systems for biological wastewater treatment in the pharmaceutical and cosmetic industry by selecting the composition of phytomeliorant plants" (2021). 


\section{REFERENCES}

1. Kłosowski S., Kłosowski G. 2001. Water and swamp plants. Oficyna wydawnicza Multico. Warszawa, 335

2. Moore B.C., Funk W.H., Anderson E. 1994. Water quality, fishery and biologic characteristic in a shallow, eutrophic lake with dense macrophyte populations. Lake Reservoir Managem., 8(2), 175-188.

3. Aalami M.T., Abbasi H., Nourani V. 2018. Sustainable management of reservoir water quality and quantity through reservoir operational strategy and watershed control strategies. International Journal of Environmental Research, 12, 773-788. DOI: 10.1007/s41742-018-0130-y

4. Agula C., Akudugu M.A., Mabe F.N., Dittoh S. 2018. Promoting ecosystem-friendly irrigation farm management practices for sustainable livelihoods in Africa: the Ghanaian experience. Agricultural and Food Economics, 6(1), DOI: 10.1186/ s40100-018-0109-1

5. Balzan M.V., Caruana J., Zammit A. 2018. Assessing the capacity and flow of ecosystem services in multifunctional landscapes: evidence of a rural-urban gradient in a Mediterranean Small Island State. Land Use Policy, 75, 711-725.

6. Chernicharo C.A.L., Van Lier J., Noyola A., Ribeiro T.B. 2015. Anaerobic sewage treatment: state of the art, constraints and challenges. Reviews in Environmental Science and BioTechnology, 1-31.

7. Oliveira S.M.A.C., Von Sperling M. 2011. Performance evaluation of different wastewater treatment technologies operating in a developing country. Journal of Water, Sanitation and Hygiene for Development, 1(1), 37-56.

8. Bortolini L., Zanin G. 2018. Hydrological behaviour of rain gardens and plant suitability: A study in the veneto plain (north-eastern Italy) conditions. Urban Forestry \& Urban Greening, 34, 121-133. DOI: 10.1016/j.ufug.2018.06.007

9. Von Sperling M., Oliveira S.M.A.C. 2009. Comparative performance evaluation of full-scale anaerobic and aerobic wastewater treatment processes in Brazil. Water Science and Technology, 59(1), 15-22.

10. Tleukeyeva A., Alibayev N., Pankiewicz R., Issayeva A.U. 2021. The possibility of using green algae as fertilizer in agriculture. Reports of NAS RK 1(2021), 21-26.

11. Piperd Z., Bau M. 2013. Normalized Rare Earth Elements in Water, Sediments, and Wine: Identifying Sources and Environmental Redox Conditions. American Journal of Analytical Chemistry, 4, 69-83.

12. Adams F.S., MacKenzie D.R., Cole H.Jr., Price M.W. 1971. The influence of nutrient pollution levels upon element constitution and morphology of Elodea canadensis. Enviro. Poll. 1, 285-298.
13. Khan M.U., Moinuddin A., Shaukat S.S., Nazim K., Qadeer M.A. 2013. Effect of industrial waste on early growth and Phyto remediation potential of avicennia marina (Forsk) vierh. Pak. J. Bot., 45(1), 17-27.

14. Mitsch W.J., Jørgensen S.E. 2004. Ecological Engineering and Ecosystem Restoration. John Wiley \& Sons, Inc., New York, 4-11.

15. McGrath S.P., Zhao F.J., Lombi E. 2002. Phytoremediation of metals, metalloids, and radionuclides. Adv. Agron., 75, 1-56.

16. Vymazal J. 2009. The use constructed wetlands with horizontal sub-surface flow for various types of wastewater. Ecol. Eng., 35, 1-17.

17. Mustapha H.I., Gupta P.K., Yadav B.K., van Bruggen J.J.A., Lens P.N.L. 2018. Performance evaluation of duplex constructed wetlands for the treatment of diesel contaminated wastewater. Chemosphere. DOI:10.1016/j.chemosphere.2018.04.036

18. Simi A. 2000. Water quality assessment of a surface flow constructed wetland treating oil refinery wastewater. In K. R. Reddy (Ed.), 7th International Conference on Wetlands System for Water Pollution Control. 3, pp. 1295-1304. Lake Buena Vista, Boca Raton, Florida, USA: IWA. Retrieved January 17, 2011.

19. Katanskaya V.M. 1981. Higher aquatic vegetation of the continental reservoirs of the USSR. 256.

20. Lee H.K. 2018. The potential implementation of green infrastructure assessment using highresolution national agriculture imagery program data for sustainable hazard mitigation. International Journal of Sustainable Development \& World Ecology, 25(4), 371-381. DOI: 10.1080/13504509.2017.1409821

21. Li Y., Zhang B., Li G., Luo W. 2018. Osmotic membrane bioreactor and its hybrid systems for wastewater reuse and resource recovery: Advances, challenges, and future directions. Current Pollution Reports, 4, 23-34. DOI: 10.1007/s40726-018-0080-1

22. MacIvor J.S., Sookhan N., Arnillas C.A., Bhatt A., Das S., Yasui S.L.E., Cadotte M.W. 2018. Manipulating plant phylogenetic diversity for green roof ecosystem service delivery. Evolutionary Applications, 11(10), 2014-2024. DOI: 10.1111/eva.12703

23. Martinuzzi S., Ramos-González O.M., Muñoz-Erickson T.A., Locke D.H., Lugo A.E., Radeloff V.C. 2018. Vegetation cover in relation to socioeconomic factors in a tropical city assessed from sub-meter resolution imagery. Ecological Applications, 28(3), 681-693. DOI: 10.1002/eap.1673

24. Mor S., Chhavi M.K., Sushil K.K., Ravindra K. 2018. Assessment of hydrothermally modified fly ash for the treatment of methylene blue dye in the textile industry wastewater. Environment, Development and Sustainability, 20, 625-639. DOI: 10.1007/s10668-016-9902-8 
25. Nedelciu C.E., Ragnarsdottir K.V., Stjernquist I. 2018. From waste to resource: A systems dynamics and stakeholder analysis of phosphorus recycling from municipal wastewater in Europe. Ambio, 48, 741-751. DOI: 10.1007/s13280-018-1097-9

26. Noori O., Ebrahimnejad R., Deihimfard R. 2018. Impact assessment of green infrastructure on surrounding microclimate (case study: Tehran's Nature Bridge). Orsini F., Gianquinto G.P., Pennisi G., Cremonini L., Georgiadis T. (Eds.). International Society for Horticultural Science, 279-282.

27. Pratiwi R.D., Fatimah I.S., Munandar A. 2018. Spatial planning for green infrastructure in Yogyakarta City based on land surface temperature. Kaswanto R.L. Ed. Institute of Physics Publishing.

28. Purvis B., Mao Y., Robinson D. 2018. Three pillars of sustainability: In search of conceptual origins. Sustainability Science, 14, 681-695. DOI: 10.1007/ s11625-018-0627-5

29. Qiu W., Meng F., Wang Y., Fu G., He J., Savic D., Zhao H. 2018. Assessing spatial and temporal variations in regional sustainability in Mainland China from 2004 to 2014. Clean Technologies and Environmental Policy, 20, 1185-1194. DOI: 10.1007/s10098-018-1540-4

30. Radonic L. 2018. When catching the rain: A cultural model approach to green infrastructure in water governance. Human Organization, 77(2), 172-184. DOI: $10.17730 / 0018-7259-77.2 .172$

31. Saeed M.A., Ma H., Yue S., Wang Q., Tu M. 2018. Concise review on ethanol production from food waste: Development and sustainability. Environmental Science and Pollution Research, 25, 2885128863. DOI: 10.1007/s11356-018-2972-4

32. Salgado I., Carcamo H., Carballo M.E., Cruz M., Duran M.C. 2018. Domestic wastewater treatment by constructed wetlands enhanced with bioremediating rhizobacteria. Environmental Science and Pollution Research, 25, 20391-20398. DOI: 10.1007/ s11356-017-9505-4

33. Straupe I., Liepa L. 2018. The relation of green infrastructure and tourism in urban ecosystem. Jelgava, Latvia: Latvia University of Agriculture, 111-116.

34. Sudarsan J.S., Annadurai R., Mukhopadhyay M., Chakraborty P., Nithiyanantham S. 2018. Domestic wastewater treatment using constructed wetland: An efficient and alternative way. Sustainable Water Resources Management, 4, 781-787. DOI: 10.1007/ s40899-017-0164-X

35. Khan M.U., Moinuddin A., Shaukat S.S., Nazim K., Qadeer M.A. 2013. Effect of industrial waste on early growth and Phyto remediation potential of avicennia marina (Forsk) vierh. Pak. J. Bot., 45(1), 17-27. 